\title{
COMMUNITY TRANSACTIONS AND MEDIA TOWARDS GOOD GOVERNANCE
}

\author{
Hery B. Cahyono \\ Universitas Muhammadiyah Jember \\ herybcahyono@gmail.com
}

\begin{abstract}
:
Society and the media have a significant role to realize the cleant governor as a characteristic of modern society. The media can provide an open flow of information from the public to all parties who are members of a political system. The flow of information from the public is the raw material for making policies in a country and the media acts as a tool to shape public opinion. It is no exaggeration that open communication is fresh blood that will provide power to realize good governance.
\end{abstract}

Keywords: Community Transactions, Media

\section{INTRODUCTION}

\section{Social Transaction}

Life in the world in general is not completely free, all require sacrifice. Someone will do an action in the hope of getting a more pleasant reward whether it is in the form of physical or non-physical rewards. That is life that cannot be separated from human efforts to meet the needs that ultimately affect behavior.The theory of social exchange developed by George C. Homan believes that the structure of development does not apply mechanically as a machine (Zeitlin, Irving M, 1998: 93) but is bridged by human behavior. In existing social structures one cannot describe institutions solely through relationships with other institutions. Malinowski illustrates that institutions not only connect with one another, but also connect the individual needs of members of the community (Zeitlin, Irving M, 1998: 93). The act of social behavior intended by Homans is an action relating to a will that results in a reward and punishment from others. George C. Homan in his book Social Behavior, Its Elementary Form: "Everyone has self-esteem, if you give benefits to others then other people will also benefit you. Position leads to responsibility, who hates, he will get the reward ... and so on (Zeitlin, Irving M, 1998: 96).

Social exchange theory provides basic assumptions that social behavior is a series of exchanges as a result of social relations. Sprecher (1998) conveys:1. Individuals try to maximize their rewards and minimize their costs. When individuals receive rewards from others, they feel appreciation.2. Attached to the concept itself involves the first two concepts of selfishness that encourage individuals to act in accordance with the perceptions and projections regarding the benefits and costs of the relationship with a 
potential exchange or exchange of sources .3. Next is interdependence refers to the level at which a person's results depend on others (Budyatna, Muhammad, 2015: 364).

Reward-based social exchange is different from economic-based exchange. Economic exchange specifically includes legal obligations, while social exchange depends on trust and goodwill (Budyatna, Muhammad, 2015: 364). Voluntary social exchanges do not involve coercion of rights and obligations. Economic exchange requires an exact breakdown of the rewards and costs from both parties, whereas social exchange leaves benefits and costs open.

\section{Social Exchange model}

This model views interpersonal relations as a trade transaction. People relate to other people because they expect something to make ends meet. Thilbault and Kelly the two leaders of this model concluded that the social exchange model was as follows:

"The basic assumption underlying our entire analysis is that each individual voluntarily enters and lives in a social relationship only as long as the relationship is satisfactory in terms of rewards and costs." Rewards, costs, profits and the level of comparison are the four main concepts in this theory (Rachmat, Jalaluddin, 1998: 121).

Reward is any consequence that is considered beneficial that someone gets from a relationship. The reward can be in the form of money, social acceptance, or support for the value it holds.

Jalaluddin Rachmat continues that the value of a reward varies from one person to another, and the value between one time and another is different. For the rich it may be that social acceptance, appreciation and confirmation are more valuable than material rewards. Conversely for poor people interpersonal relationships that can solve economic difficulties are more valuable than the rewards that are social acceptance and knowledge. The affairs of basic needs determine the reward valuation.

Costs are fees that must be paid in a social exchange. These costs can take the form of time, effort, conflict, anxiety and collapse of self-esteem and other conditions that can deplete an individual's source of wealth or can cause unpleasant effects. As with rewards, the costs change according to the time and people involved in them.

Reward calculations are results or rewards minus costs. Jalaluddin Rachmat continues if someone feels in an interpersonal relationship does not produce a long time then someone will look for another relationship. When friends with people who are stingy and stupid, it only helps a lot and does not get profit or profit. Homan said that there is no exchange that takes place if the two parties are not mutually beneficial (Zeitlin, Irving M, 1998: 93). Relationships like this according to the theory of social exchange will not last long then crack and even break up. Eventually it will be replaced by a more profitable relationship.

Jalaludin Rachmat continued that the level of comparison shows the standard size or which is used as criteria in assessing the relationship of individuals at the present time that much depends on past experience. If the past has experienced satisfying interpersonal relationships, it will assess the current relationship lower. A girl who has had very good interpersonal communication in the past with her boarding friend, so if now dealing with a new boarding friend is less satisfying, she will judge her relationship to be lower. Then 
Muhammdyad Budyatna mentions that the degree to which a person's results depend on others (Budyatna, Muhammad, 2015: 364).

Furthermore exchange theory connects the amount of reward with aspects of justice. According to Homan that:

"... justice in social behavior is characterized by a fundamental rule that every person involved in the exchange expects a proportional reward for his costs, he expects that the greater the reward the greater the cost, thus the reward network or the profit of each human must be proportionate to the investment. The greater the investment he gives, the greater the benefits (Zeitlin, Irving M, 1998: 103). "

If the sense of justice is not achieved Homan said emotional behavior or anger will occur. When justice fails not only shows anger but avoids activities that cause them to be in an unfavorable condition. A fair exchange according to Homan is an exchange that is mutually beneficial or seen as mutually beneficial to both parties and that justice is relative and subjective (Zeitlin, Irving M, 1998: 100-101).

Homan in The Fondamental Social Process then relates to power that if two or more individuals enter an exchange relationship, and one of them is able to change the behavior of others according to their wishes, then we can say that the person has more power over others (Zeitlin, Irving M, 1998: 113). Homan assumes that the first party and the second party

\section{Social Media}

Every communication behavior will always involve communicators, messages, channels, audiences and feedback (feedback), while the effect is the result or result of the communication process. Communication behavior is not merely flowing without a definite purpose but actually has a goal from the small to the big from the unintentional to the planned. Smiling with friends is not just about smiling but also wants to maintain the harmony of relationships.

The community will rise up its power to participate in every activity if the community has the hope and opinion that what is done gets a balanced outcome with the sacrifice. Social media has been facilitating and bridging the steps of the community with various information technology-based services. During this time there has been a very large shift from journalism based on an institution towards community participation at large. Information technology has made it easy for anyone to be involved in the process of finding news to investigation.

When approached to the information processing system, the discussion process actually involved the community massively. Community participation in the information processing process is a huge reward for anyone involved in it. The reward is very possible for people to discuss, be creative to freely process information freely. Previously the truth was only owned by who owns the media and who has financial sufficiency, but now at any time, anywhere and anyone can be involved in the information processing. Depending on the will and mastery of information technology.

The message conveyed by the public became diverse starting in the form of writing, photos to videos. Freedom to collect information is a form of social exchange that provides positive energy to the community. The form of rewards or gifts are not 
necessarily in the form of material but can also be expressive. This form is actually a very significant form of learning, especially when viewed from the theory of the need for inclusion is a very expensive fee.

Rewards or prizes trigger community involvement to improve the quality of the message they present. No wonder almost all people who are "literate" technology with the sacrifice of time and the media continue to strive to pursue and have in order to pursue the quality of messages, especially in the form of better pictures and videos. Communication media such as cell phones are now the hallmarks of modern society. Previously, one person's parameters of breadth of insight could be seen from the media that were read whether local, regional, national to international levels. If what Time magazine reads, the insights started are global, but they do not apply at this time. Anyone can hunt for messages or information across the continent via the internet.

A very valuable social and community exchange is if the message delivered has a significant impact. Community involvement in various cases has proven that large-scale problem disclosure starts from the role of the small-scale community. This is the most meaningful social exchange for society in general. When likened to the exchange it is the first champion or gold medal in a sports event. The reward is able to generate great power to realize good governance towards a better order.

One thing that cannot be forgotten is when the media is able to popularize the various results of policies that have been taken by the political system in a country. This feedback is the raw material that must be provided by the mass media so that the community is able to process data into information. A broad, open and balanced picture is needed so that the community can process it properly and accurately. During this atmosphere has occurred, the mass media has done much to serve the needs of the community to be involved in the decision making process.

\section{Agenda}

Freedom of expression in many countries as a basis for the cleant governor has been wide open. Only often this openness often causes haste in packaging messages. The events are still incomplete and in the hereafter but are rushed to be broadcast by the media. There is even a tendency for the media to roll hot balls to the public. Openness can also cause public apathy, because the agenda setting theory in communication is often applied. Low value news is the main agenda that is excessive. So there is an element of omission from the community, let the mass media get busy with itself, we are not related to the mass media. Who is wrong, of course, the mass media.

The magnitude of the role of the community supported by social media at least must also be supported by the ability of the political system to process information into a policy that supports the efforts of the cleaver gavernet. Often the political system is not adaptive to the dynamics of information that develops, the system is a lot of struggling with the interests of representative institutions and also the government. The mass media becomes very necessary to collaborate with pressure groups to push information into an input for the political system as a fuel for the operation of a system. Now the community and the media should work together in a balanced manner so that social exchange is balanced and can encourage the realization of good governance. 
Proceeding ICOGISS 2019

Page 208-212. ISBN: 978-602-6 988-75-1

Web Jurnal Online: jurnal.unmuhjember.ac.id

By: Hery B. Cahyono

Community Transaction and Media Towards Good Governance

\section{Reference}

Birowo, M. Antonius, Metode Penelitian Komunikasi Teori Dan Praktek, Gitanyali, Yogyakarta, 2004

Budyatna, Muhammad, Teori-Teori Komunikasi Antar-Pribadi, Kencana, Jakarta, 2015

Junaedi Fajar, Komunikasi Politik, Teori, Aplikatif Dan Strategi Di Indonesia, Buku Litera, Yogyakarta, 2013

Mulyana Deddy, Komunikasi Antarbudaya, Remaja Rosdakarya, Bandung, 1998

Mufid Muhamad, Etika Filsafat Dan Komunikasi, Kencana, Jakarta, 2009

Nurhadi, Zikri Fachrul, Teori-Teori Komunikasi(Teori Komunikasi Dalam Persektif Penelitian Kualitatif)Ghalia Indonesia,Bogor, 2015

Rakhmat, Jalaluddin, Psikologi Komunikasi, Remaja Rosda Karya, Bandung, 1998.

Sobur, Alex, Filsafat Komunikasi Tradisi Dan Metode Fenomenologi, Remaja Rosdakarya, Bandung, 2013.

Zeitlin, Irving M, Memahami Kembali Sosiologi, Gajah Mada University Press, Yogyakarta, 1998. 